\title{
PENGARUH PENAMBAHAN KITOSAN DAN GLISEROL PADA BIOPLASTIK DARI LIMBAH AIR CUCIAN BERAS (Oriza sp.)
}

\author{
Siti Iqlima Layudha*, Rita Dwi Ratnani, Harianingsih \\ Jurusan Teknik Kimia, Fakultas Teknik, Universitas Wahid Hasyim \\ Jl. Menoreh Tengah X/22, Sampangan, Semarang 50236. \\ *E-mail: iqlimayudha29@gmail.com
}

\begin{abstract}
Abstrak
Bioplastik atau yang sering disebut plastik biodegradable, merupakan salah satu jenis plastik yang hampir keseluruhannya terbuat dari bahan yang dapat diperbaharui dan mudah diuraikan oleh alam. Bioplastik pada penelitian ini berbahan dasar air cucian beras dengan penambahan gliserol dan kitosan. Tujuan dari penelitian ini adalah untuk mengetahui pengaruh penambahan variasi gliserol dan variasi gliserol-kitosan pada bioplastik dari air cucian beras. Penelitian diawali dengan membuat selulosa bakteri atau yang sering disebut dengan nata dari air cucian beras menggunakan metode fermentasi. Tahapan dilanjutkan dengan melakukan variasi penambahan gliserol 1\%, 2\%, 3\%, 4\% dan penambahan kitosan $1 \%, 2 \%, 3 \%, 4 \%$ dengan cara merendam bioplastik-gliserol yang sebelumnya telah dikeringkan dalam larutan kitosan. Hasil karakterisasi uji tarik menunjukkan bahwa bioplastik dari air cucian beras dengan kekuatan tarik optimum pada variasi penambahan gliserol 1\% yaitu 0,029 N/mm${ }^{2}$. Sedangkan pada penambahan variasi gliserol-kitosan, bioplastik dari air cucian beras memiliki kekuatan tarik optimum pada penambahan kitosan 2\%, yaitu 0,076212 $\mathrm{N} / \mathrm{mm}^{2}$.
\end{abstract}

Kata Kunci: Air cucian beras, gliserol, kitosan

\section{PENDAHULUAN}

Sampah plastik yang sangat sulit diuraikan oleh mikroba di dalam tanah kini semakin menjadi permasalahan yang pelik bagi lingkungan kita. Masalah juga timbul pada bahan pembuatan plastik yang keadaannya di alam semakin menipis yaitu minyak bumi, gas alam dan batu bara.

Sebagai solusi permasalahan tersebut, kini telah banyak dikembangkan bioplastik atau plastik biodegradable, yaitu plastik yang terbuat dari bahan-bahan yang dapat diperbarui dan mudah diuraikan oleh mikroba. Bioplastik tersebut dapat dibuat dari bahan-bahan organik seperti selulosa, kolagen, pati, kasein, protein, atau lipid (Sinaga, 2014).

Pada penelitian ini, bioplastik dibuat dari pemanfaatan limbah air cucian beras. Air cucian beras merupakan air sisa proses pencucian beras yang pada umumnya jarang dimanfaatkan sehingga hanya dibuang, padahal air sisa tersebut masih mengandung karbohidrat jenis pati sebanyak $76 \%$ pada beras pecah kulit. Menurut Chrysti (2013), kandungan karbohidrat pada air cucian beras tersebut memenuhi syarat untuk media pertumbuhan bakteri Acetobacter xylinum yang berperan dalam pembuatan nata sebagai langkah awal dari pembuatan bioplastik pada penelitian ini.

Sinaga (2014) meneliti pengaruh penambahan gliserol terhadap sifat dan karakteristik bioplastik dari pati umbi talas. Sintesis dan karakterisasi bioselulosa berbahan dasar nira aren-kitosan dengan penambahan gliserol sebagai plasticizer telah diteliti oleh Ayu (2013). Pembuatan bioplastik dari air cucian beras telah dilakukan oleh Alifia (2012) dengan penambahan kitosan untuk mengetahui sifat dan karakteristik bioplastik.

Berdasarkan beberapa penelitian yang disebutkan di atas, maka dapat diketahui bahwa pada penelitian sebelumnya telah dikaji kandungan dan manfaat limbah air cucian beras, sehingga air cucian beras tersebut berpotensi sebagai bahan baku pembuatan bioplastik yang pada penelitian ini divariasi dengan penambahan gliserol dan kitosan untuk meningkatkan sifat mekaniknya.

\section{METODOLOGI}

\section{Bahan-bahan}

Bahan-bahan yang digunakan pada penelitian ini antara lain, air cucian beras, asam asetat teknis, gula, kitosan cangkang udang, urea, gliserol, Acetobacter xylinum, aquadest. 


\section{Alat-alat}

Bahan-bahan yang digunakan pada penelitian ini yaitu gelas ukur, beaker glass, pipet, kompor listrik, magnetic stirrer, kertas $\mathrm{pH}$, nampan, alumunium foil, oven, alat uji tarik Brookfield CT3.

\section{Lokasi Penelitian}

Pembuatan selulosa bakteri dari fermentasi pati dalam medium air cucian beras dengan penambahan kitosan dan gliserol menggunakan Acetobacter xylinum dilakukan di Laboratorium Proses dan Instrument Program Studi Teknik Kimia Fakultas Teknik Unwahas dan uji tarik di Laboratorium Terpadu Universitas Diponegoro Semarang.

\section{Prosedur Penelitian}

Bioplastik dalam penelitian ini diawali dengan membuat selulosa bakteri yang banyak disebut sebagai nata, merupakan hasil fermentasi air cucian beras menggunakan bakteri Acetobacter xylinum.

Air cucian beras dihasilkan dari beras $1 \mathrm{~kg}$ yang dicuci dengan 1,5 L air. Air cucian beras tersebut dididihkan kemudian ditambahakan asam asetat dan urea 2,5\% (m/v). Setelah agak dingin ditambahkan gula 25 gr. Penambahan asam asetat bertujuan untuk meningkatkan keasaman medium air cucian beras, yaitu agar ber-pH 4. Menurut Riwayati (2006:16), tingkat keasaman optimum untuk pembentukan nata adalah 4-5,5. Sedangkan penambahan urea dan gula adalah untuk nutrisi bakteri Acetobacter xylinum.

Air cucian beras yang sudah ditambahkan bahan-bahan tersebut dituangkan dalam wadah nampam sebanyak $200 \mathrm{~mL}$ kemudian ditambahkan variasi gliserol $1 \%, 2 \%$, $3 \%$ dan $4 \%(\mathrm{~m} / \mathrm{v})$ dengan masa pembentukan nata selama sepuluh hari. Nata yang telah terbentuk kemudian di keringkan dengan oven pada suhu $\pm 80{ }^{\circ} \mathrm{C}$ selama 1,5 jam untuk kemudian bioplastik variasi gliserol tersebut dikarakterisasi kekuatan tariknya menggunakan alat uji tarik Brookfield CT3.

Tahap berikutnya yaitu penambahan variasi kitosan dengan cara merendam bioplastik variasi gliserol yang telah kering tadi dalam $1 \%, 2 \%, 3 \%$ dan $4 \%(\mathrm{~m} / \mathrm{v})$ kitosan yang telah dilarutkan dalam $100 \mathrm{~mL}$ asam asetat $1 \%$ selama 24 jam lalu dikarakterisasi dengan alat uji tarik Brookfield CT3 di Laboratorium Terpadu Universitas Diponegoro Undip Semarang.

\section{HASIL DAN PEMBAHASAN \\ Hasil Uji Tarik Bioplastik Variasi Gliserol}

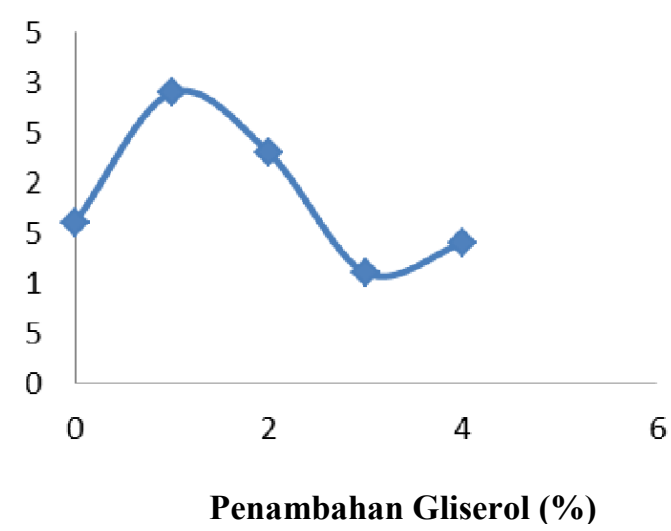

Gambar 1 Grafik hubungan kuat tarik
bioplastik dengan penambahan variasi
gliserol

Uji tarik terhadap bioplastik dilakukan di Laboratorium Terpadu Universitas Diponegoro Semarang menggunakan alat Brookfield CT3 dengan metode tension. Diketahui bioplastik tanpa variasi gliserol maupun kitosan memiliki kekuatan tarik sebesar $0,016 \mathrm{~N} / \mathrm{mm}^{2}$, pada bioplastik dengan variasi gliserol $1 \%$ memiliki kekuatan tarik $0,029 \mathrm{~N} / \mathrm{mm}^{2}$, pada bioplastik dengan variasi gliserol 2\% memiliki kekuatan tarik 0,023 $\mathrm{N} / \mathrm{mm}^{2}$, pada bioplastik dengan variasi gliserol $3 \%$ memiliki kekuatan tarik $0,011 \mathrm{~N} / \mathrm{mm}^{2}$ dan pada bioplastik dengan variasi gliserol $4 \%$ memiliki kekuatan tarik sebesar $0,014 \mathrm{~N} / \mathrm{mm}^{2}$.

Berdasarkan gambar 1 dapat diketahui bahwa penambahan gliserol berpengaruh pada sifat mekanik bioplastik dari air cucian beras, terbukti dengan bertambahnya kekuatan tarik pada bioplastik tanpa penambahan gliserol dengan bioplastik dengan penambahan gliserol. Nilai kuat tarik pada bioplastik-gliserol menurun seiring dengan banyaknya penambahan gliserol. Penurunan nilai kuat tarik ini terkait dengan adanya ruang kosong yang terjadi karena adanya ikatan antar polisakarida yang diputus oleh gliserol. Sehingga menyebabkan ikatan antar molekul dalam film plastik semakin melemah (Anggarini, 2013). Selain itu, menurut Bourtoom (2008) juga menyatakan bahwa kenaikkan penambahan konsentrasi gliserol sebagai plasticizer menyebabkan nilai kuat tarik semakin berkurang seiring dengan berkurangnya interaksi intermolekul. Interaksi berkurang karena adanya gliserol yang menyisip dan 
menghilangkan ikatan hidrogen di antara polisakarida.

Penambahan $1 \%$ gliserol pada bioplastik memberikan sifat mekanik paling optimum. Hal ini karena bioplastik dengan penambahan gliserol $1 \%$ memiliki kekuatan tarik paling besar, yaitu $0,029 \mathrm{~N} / \mathrm{mm}^{2}$. Bioplastik-gliserol dengan nilai kuat tarik paling optimum tersebut yang kemudian divariasi dengan kitosan.

\section{Hasil Uji Tarik Bioplastik-Gliserol dengan Penambahan Variasi Kitosan}

Diketahui bioplastik-gliserol dengan penambahan kitosan 1\% memiliki kekuatan tarik $0,051089 \mathrm{~N} / \mathrm{mm}^{2}$, pada bioplastik-gliserol dengan penambahan kitosan $2 \%$ memiliki kekuatan tarik $0,076212 \mathrm{~N} / \mathrm{mm}^{2}$, pada bioplastik-gliserol dengan penambahan kitosan $3 \%$ memiliki kekuatan tarik $0,052246 \mathrm{~N} / \mathrm{mm}^{2}$ dan pada bioplastik-gliserol dengan penambahan kitosan 4\% memiliki kekuatan tarik sebesar $0,044304 \mathrm{~N} / \mathrm{mm}^{2}$. Penambahan 2\% kitosan pada bioplastik memberikan sifat mekanik paling optimum. Hal ini karena bioplastik dengan penambahan gliserol 2\% memiliki kekuatan tarik paling besar, yaitu $0,076212 \mathrm{~N} / \mathrm{mm}^{2}$.

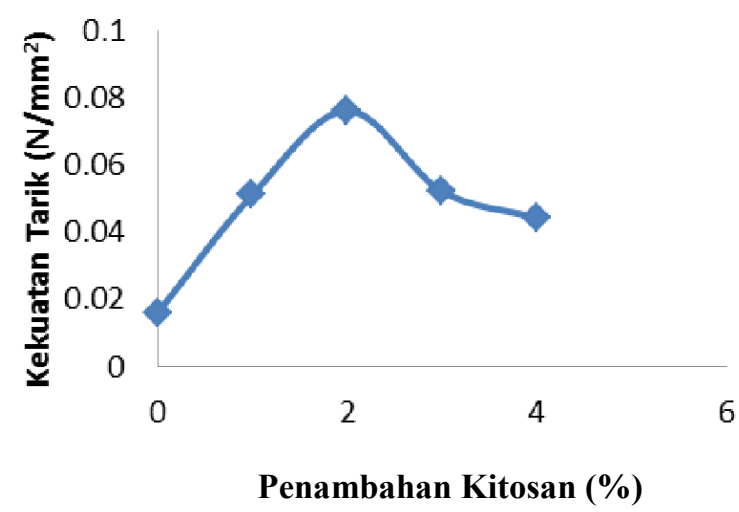

\section{Gambar 2 Grafik hubungan kuat tarik bioplastik dengan penambahan variasi gliserol-kitosan.}

Berdasarkan gambar 2 diketahui bahwa nilai kuat tarik pada bioplastik-kitosan menurun seiring dengan banyaknya penambahan kitosan. Penambahan kitosan pada bioplastik mengakibatkan terjadinya ikatan hidrogen antara gugus $\mathrm{OH}$ selulosa bakteri dan gugus $\mathrm{OH}$ kitosan. Adanya ikatan hidrogen pada selulosakitosan bakteri mengakibatkan mobilitas molekuler selulosa-kitosan bakteri berkurang.
Pengurangan mobilitas molekuler ini menyebabkan menurunnya kekuatan tarik bioplastik (Rahayu \& Rohaeti, 2012).

\section{KESIMPULAN}

Penambahan gliserol mempengaruhi sifat mekanik berupa kekuatan tarik bioplastik dari air cucian beras, nilai kuat tarik pada bioplastik-gliserol menurun seiring dengan banyaknya penambahan gliserol. Penambahan $1 \%$ gliserol memiliki kekutan tarik optimum, yaitu $0,029 \mathrm{~N} / \mathrm{mm}^{2}$.

Penambahan kitosan mempengaruhi sifat mekanik berupa kekuatan tarik bioplastik dari air cucian beras, nilai kuat tarik pada bioplastikkitosan menurun seiring dengan banyaknya penambahan kitosan. Penambahan 2\% kitosan memiliki kekuatan tarik optimum, yaitu $0,076212 \mathrm{~N} / \mathrm{mm}^{2}$.

\section{DAFTAR PUSTAKA}

Alifia A., dkk., (2012), Preparasi dan Karakterisasi Bioplastik Dari Air Cucian Beras Dengan Penambahan Kitosan, E-Journal Kimia S1 II, Vol. 1, No. 2. Universitas Negeri Yogyakarta, Yogyakarta.

Anggarini, (2013), Aplikasi Plasticizer Gliserol Pada Pembuatan Plastik Biodegradable Dari Biji Nangka. Skripsi. Jurusan Kimia FMIPA, Universitas Negeri Semarang, Semarang.

Ayu R., (2013), Sintesis dan Karakterisasi Bioselulosa-Kitosan Dengan Penambahan Gliserol Sebagai Plasticizer. Skripsi. Universitas Airlangga, Surabaya.

Bourtoom T., (2008), Plasticizer Effect On The Properties of Biodegradable Blend Film From Rice Starch-Chitosan. Departement of Material Product Technology, Faculty of Agro-Industry, Prince of Songkla University. Hai Yai, Songkhla, Thailand.

Chrysti K., (2013), Frmentasi Aneka Bahan Baku Berbasis Kearifan Lokal Dalam Pembuatan Nata Sebagai Produk Ekspor. Skripsi. Program Studi Pendidikan Biologi, FKIP, Universitas Sebelas Maret, Solo.

Rahayu T., dan Rohaeti E., (2012), Sifat Mekanik Selulosa Bakteri Dari Air Kelapa Dengan Penambahan Kitosan, Jurnal Penelitian Saintek, Vol. 19, Nomor 2, Fakultas Matematika dan 
Ilmu Pengetahuan Alam, Universitas Negeri Yogyakarta, Yogyakarta.

Riwayati I., (2006), Buku Petunjuk Praktikum Bioproses, Universitas Wahid Hasyim, Semarang.

Sinaga R., dkk., (2014), Pengaruh Penambahan Gliserol Terhadap Sifat Kekuatan Tarik Dan Pemanjangan Saat Putus Bioplastik Dari Pati Umbi Talas. Jurnal Teknik Kimia, Vol. 3, No. 2. Universitas Sumatera Utara, Medan. 